UDC 159.922.7:376:316

Armenuhi AVAGYAN,

Lilith BAGHDASARYAN,

Karine SARGSYAN

\title{
CHANGING STEREOTYPES WITH REGARD TO SPECIAL NEEDS THROUGH CHILDREN'S LITERATURE
}

\begin{abstract}
We had the idea of this research, when we learned, that the children's book about special needs: R.J. Palacio "Wonder" was translated into Armenian for the first time.

Books on this topic have not been written yet by Armenian authors. The point is that during Soviet years the working assumption was that all the people were "like each other", perfect, beautiful, without problems, without disorders; all those, who did not meet those criteria (who had visual, auditory, physical, mental, even speech and communication limitations), grew up and spent their lives in special boarding institutions, segregated from their families and society. Being ashamed of their children, who were not ideal, the parents kept them at home, hidden from acquaintances, neighbours, sometimes even from relatives.

Attitudes have begun to change since then, and inclusive education has been a goal in Armenia since 2001. Despite the 15-year history of efforts at inclusive education, acceptance of people with special needs is still not evident in all corners of Armenian society. One of the most prevalent shortcomings is the stereotyping of people with special needs.

We decided to use the reading of the book R.J. Palacio "Wonder" for the purpose of helping people confront their attitudes and stereotypes about disabilities as they explored the lives in this unique book.
\end{abstract}

Keywords: inclusive education, bibliotherapy, self-esteem measurement, M. Rokeach Value Survey, pre-reading discussion, post-reading discussion, a meeting with children with special needs.

At the present stage of society development, the attitude towards people with special needs is getting more and more humane. In Armenia, steps are taken towards this as well. The transition to inclusive education is one of indicators. The assessment of the child not from the perspective of problems he/she has, but from the perspective of his/her resources and potential is the evidence of the above mentioned. However, the issue of preception of "different individual or white crow" is still open. Often classmates, who do not have experience of communication with these kinds of children, and face them for the first time, can spontaneously react in various ways, from rudeness and laughter to pity, that is equally unacceptable. The issue of regulation of perception of "different" individual is becoming 
actual, finding ways to teach the child to perceive the individual with deep respect towards his/her strong points, fully accepting his/her differences. The strategy of such an influence led us to the idea of bibliotherapy application, since reading is part of both learning and leisure for schoolchildren. Tale and story can be considered as natural way of information indirect transfer, instead of direct instructions and preachiness. It is typical for children to identify themselves with the main story characters, and with the help of the book the child can deeply experience the feelings of the main character.

Children's literature can be a way to share powerful examples of how we all may or may not relate to individual differences. This can be especially true for understanding how disabilities impact the lives of individuals and their families and friends. Reading children's literature can be instrumental in changing readers' attitudes about stereotypes, and it is important for educators that these changes be beneficial (Kurtts \& Gavigan, 2008). Considering this fact, we decided to use the reading of the book R.J. Palacio "Wonder" for the purpose of helping people confront their attitudes and stereotypes about disabilities as they explored the lives in this unique book. The translation of Wonder to Armenian was published in 2015. The story is about a 10-year old American boy August Pullman /Auggie/, who suffers from Treacher Collins syndrome, which is characterized by craniofacial deformities of the child.

In our work with this book, we were interested in looking at how children build positive understandings of disability from children's literature and how their attitudes, beliefs, and stereotypes are changed. The book should not be read as a fiction, but applied as a means of bibliotherapy, which includes the following stages:

a) pre-reading discussion,

b) post-reading discussion,

c) a meeting with children with special needs.

After the pre-reading discussion, the children were given time for reading the book and then discuss again after reading. Debates were included as part of the discussions. These supported the children in identifying differences of people, as well as perceiving the importance of equal rights and social inclusion. Concepts, such as "difference", "prejudice", "tolerance", "justice" in a relationship with people, who are different from them, were discussed, as well as issues were analysed on how the person reacts, when the other one is drastically different, and whether it is possible to control the reaction. They also identify the notion of friend, realize the difficulties of Auggie's friends, describe Auggie as a friend, and so on.

The organization of meetings with peers is a critical component because not all the schools carry out inclusive education in Armenia; hence, the children do not always have experience interacting with their peers with special needs. The accomplishment of this stage served as a base for research questions and the study.

The research question was:

- When to organize the meeting, before or after reading the book with the purpose of making bibliotherapy effective?

With the intention of finding the answer for the first question, we formed two groups of 14-year old students, 15 participants for each group. In one of the groups (group A), 
participants met children with special needs (peers) before reading the book and taking part in the discussions. The meeting was effective and full of positive emotions; the children quickly got acquainted with their special needs peers and developed a warm relationship. There was a long-lasting farewell, even some of the children wanted to go back after leaving and continue the interaction.

The participants of the group B read the book at first and took part in the discussions; afterwards they met children with special needs. From the very beginning the children had hesitation with regard to the visit, they thought it would be emotionally difficult, some of them were excited during the meeting.

In order to explain the effectiveness of bibliotherapy in the two cases we examined the behaviour of the above-mentioned children. Also, comparisons were examined of before and after scores on a self-esteem scale (Dembo-Rubinstein) as well as a value system scale (Rokeach Value Survey).

Self-esteem measurement by the scale of Dembo-Rubinstein in the modification of

\section{A. M. Prichozhan.}

The methodology is based on direct assessment (scaling) of a number of personal characteristics of students, such as health, abilities, character, and so on. The ones being examined are offered to mark by certain signs the level of development of the above mentioned qualities they have on vertical lines (a measure of self-esteem) and the level of claims, i.e. the development level of the same qualities that they would be satisfied with. Each of them is offered a methodology form, containing instructions and assignments.

\section{Accomplishment of the research}

Instructions: "Everyone appreciates his/ her abilities, capabilities, nature and etc. The development level of each quality, aspect of human personality can be divided to represent a vertical line, the lower point of which will symbolize the lowest development level, and the top - the highest one. You are offered seven such lines. They mean:

- health;

- intelligence, abilities;

- character;

- reputation among peers;

- the ability to do many things with your hands, capable hands;

- appearance;

- self-confidence.

Mark by a hyphen (-) on each line, how you assess the development of that quality, the sides of your personality at a particular time. After that, put a cross (x) mark, mentioning the level of development of these qualities, sides, you would be satisfied with or would feel proud of yourself.

The one being examined is given a form, showing seven lines, the height of each one is $100 \mathrm{~mm}$, with an indication of the top, bottom and middle points of the scale. The upper and the lower points are marked by notable stripes, the middle one - by a barely visible dot. 
Processing and interpretation of the results

\begin{tabular}{|c|c|c|c|c|}
\hline \multirow{2}{*}{ Parameter } & \multicolumn{3}{|c|}{ Quantitative characteristics (score) } \\
\cline { 2 - 5 } & low & average & high & Very high \\
\hline The level of claims & Less than 60 & $60-74$ & $75-89$ & $90-100$ \\
\hline The level of self-esteem & Less than 45 & $45-59$ & $60-74$ & $75-100$ \\
\hline
\end{tabular}

For revealing the important values for the child, the latter is given a list of values, without enumeration, and he/she is asked to enumerate them according to their importance.

According to Dembo-Rubinstein scale, children where asked about both their actual self-esteem and its desired level. It is assumed, that in this way the level of individual claims can be estimated. The aim of the following research is to assess the correlation between the actual and desired levels of selfesteem and on this basis to draw the conclusion concerning the usefulness of this modification of the method.

By the application of children from group A of Dembo-Rubinstein Method, it turned out, that after the experiment there was a significant increase in self-esteem of physical and mental health, decrease in health care, which means, that the child had real assessment of his/her possibilities.

There was an increase of self-esteem with regard to abilities, authorship, happiness, appearance, and self-confidence as well. It is evident from the results, that the experiment was successful and effective for the children's emotional state and self-esteem.

It was obvious, that there was a decrease in self-esteem of physical and mental health, as well as happiness of children from group B.
With the purpose of revealing the changes in value system of the same children, $M$. Rokeach Value Survey was applied. The children were given a list of values, and they had to enumerate the values according to their importance. It is well known, that the value system, as a complex personality structure, is less likely subject to change, though before and after the experiment, there were changes even in it.

Before reading the book and meeting peers with special needs, the children of group A gave importance to health $/ 95 \% /$, happy family life $/ 44 \%$ /, wisdom $/ 20 \%$ /, love $/ 16 \% /$.

After reading the book and meeting with peers with special needs, health $/ 97 \% /$ and happy family life $/ 31 \% /$ remained as important values, but the presence of good and loyal friends was given importance to as well $126 \% /$.

Before reading the book and meeting peers with special needs, the children of group B mentioned health $/ 93 \% /$, the presence of good and loyal friends $/ 29 \% /$, happy family life $/ 21,4 \% /$.

After reading and the visit, health / 98\%/, the presence of good and loyal friends $/ 36,5 \%$ / and happy family life $/ 18 \%$ / remained as important values, but the children gave importance to self-confidence as well $/ 15 \% /$. 
Conclusion

Hence, we come to the conclusion that bibliotherapy is effective, especially if meeting and interacting with children with special needs before reading the book. The supposed reasons for this fact are the following:

- When reading the book, the child imagines the one with special needs as ideal, that is why meeting the latter causes disappointment.

- When reading the book, the child identifies himself with the personage, hence after reading, the meeting gives rise to negative emotions.

- Meeting the children with special needs before reading the book gives rise to the child's emotions and empathy, though reading the book supports in caring and focusing on the individual's inner world, strengths and potential, hence the book has positive impact, and the attitude towards these children is positive as well.

As a matter of fact, effective bibliotherapy is carried out in this case.

\section{REFERENCES}

Borders, S., \& Paisley, P.O. (1992). Children's literature as a resource for classroom guidance. Elementary School Guidance and Counseling, 27(2), 131-140.

Conly, J.L. (1993). Crazy lady! New York: HarperCollins.

Cook, K.E. (2006). Bibliotherapy. Intervention in School and Clinic. 42(2). 91100.

Council for Exceptional Children's Division on Developmental Disabilities and
Special Needs Project. (2006). Dolly Gray Award for children's literature in developmental disabilities. Arlington, VA: Author. Retrieved November 15, 2006, from http://www.dddcec.org/dolly gray award.htm.

Davis, K., \& Wilson, T.L. (1992). Bibliotherapy and children's award winning books. Retrieved November 15, 2006, from ERIC database (Item ED354470)

http://eric.ed.gov/ERICDocs/data/eri cdocs $2 /$ content_storage_01 /0000000b/80/25/12/a9.pdf.

Derman-Sparks, L., \& the ABC Task Force. (1989). Antibias curriculum: Tools for empowering young children. Washington, DC: National Association for the Education of Young Children http://www.naeyc.org/. Retrieved November 15, 2006, from http://circleofinclusion.org/english/b ooks/section1/cklistblk.html. Education Libraries: Childrens Resources, Volume 31, No. 1, Spring 200827.

Dyches, T.T. (2006). The Dolly Gray Award for children's literature in DDD. Arlington, VA: Council for Exceptional Children's Division on Developmental Disabilities and Special Needs Project. Retrieved November 11, 2006, from

http://www.dddcec.org/dolly_gray_a ward.htm.

Galen, N., \& Johns, J.L. (1979). Children in conflict. School Library Journal. 26(3), 25-30.

Gavigan, K. (2007). Teaching resources center: Bibliographies. Retrieved March 
23,2007 , from

http://www.uncg.edu/soe/trc.

Gladding, S.T., \& Gladding, C. (1991). The $\mathrm{ABCs}$ of bibliotherapy and school counsellors. Elementary School Counselor, 39(1), 7-12.

Haddon, M. (2003). The Curious incident of the dog in the night-time. New York: Doubleday.

Harvey, S., \& Goudvis, A. (2000). Strategies that work: Teaching comprehension to enhance understanding. Portland, MN: Stenhouse Publishers.

Herbert, T.P., \& Kent, R. (2000). Nurturing social and emotional development in gifted teenagers through young adult literature. Roeper Review, 22(3), 167-172.

Hopkins-Best, M., \& Wiinamiki, M. (1985). Bibliotherapy for disabled students in school-to-work transition. Techniques, 1(6), 490-496.

Iaquinta, A., \& Hipsky, S. (2006). Practical bibliotherapy strategies for the inclusive elementary classroom. Early Childhood Education Journal, 34(3), 209-213.

Interstate New Teacher Assessment and Support Consortium. (2007) Interstate new teacher assessment and consortium standards. Retrieved March 26, 2007, from

http://www.ccsso.org/content/pdfs/co restrd.pdf.

International Council for Exceptional Children. (2006). Professional standards. Arlington, VA: Author. Retrieved March 26, 2007, from http://www.cec.sped.org
Kramer, P.A. (1999). Using literature to enhance inclusion. Contemporary Education, 70(2), 34-38.

Kurtts, S.A. \& Gavigan, K.W. (2008). "Understanding (Dis)abilities through children's literature." Education Libraries: Childrens Resources, Volume 31, No. 1, 23-31.

Lears, L. (2002). Becky the Brave: A story about epilepsy. Morton Grove, IL: Albert Whitman.

Lenkowsky, R.S. (1987). Bibliotherapy: A review and analysis of the literature. The Journal of Special Education, 21, 123-132.

McCarty, H., \& Chalmers, L. (1997). Bibliotherapy: Intervention and prevention. Teaching Exceptional Children, 29(6), 12-13.

Orr, L.E.; et al. (1997). Exploring developmental disabilities through literature. Teaching Exceptional Children, 29(6), 14-17.

Pardeck, J.T. (1994). Using literature to help adolescents cope with problems. $A d$ olescence, 70(114), 421-428.

Penn, A. (2003). A.D.D. not B.A.D. Terre Haute, IN: Tanglewood Press. Prater, M.A. (2003).Learning disabilities in children's and adolescent literature: How are characters portrayed? Learning Disability Quarterly, 26, 4761.

Riggio, A. (1997). Secret signs, Along the underground railroad. Honesdale, PA: Bodes Mills Press.

Roberts, A. (1984, May). Bibliotherapy: A technique for counseling blind people. Journal of Visual Impairment \& Blindness, 78(5), 197-199. 